\title{
EVALUATION OF THE USE AND RE-USE OF COTTON FABRICS AS MEDICAL AND HOSPITAL WRAPS
}

\author{
Edna Rodrigues ${ }^{1 *}$; Anna S. Levin ${ }^{2,3}$; Sumiko Ikura Sinto ${ }^{3}$; Caio Figueiredo Mendes ${ }^{3}$; Benedito Barbosa ${ }^{4}$; \\ Kazuko Uchikawa Graziano ${ }^{5}$
}

${ }^{1}$ Comissão de Controle de Infecção Hospitalar, Hospital das Clínicas da Faculdade de Medicina, Universidade de São Paulo, São Paulo, SP, Brasil; ${ }^{2}$ Departamento de Moléstias Infecciosas e Parasitárias e Grupo de Controle de Infecção Hospitalar do

Hospital das Clínicas, Faculdade de Medicina, Universidade de São Paulo, Brasil; ${ }^{3}$ Laboratório de Investigação Médica, Bacteriologia, Hospital das Clínicas da Faculdade de Medicina, Universidade de São Paulo, São Paulo, SP, Brasil; ${ }^{4}$ Laboratório de Controle de Qualidade, Escola Técnica Francisco Matarazzo, Serviço Nacional da Indústria, São Paulo, SP, Brasil; ${ }_{5}^{5}$ Departamento de Enfermagem Médico-Cirúrgica, Escola de Enfermagem, Universidade de São Paulo, São Paulo, SP, Brasil

Submitted: May 12, 2005; Returned to authors for corrections: January, 09, 2006; Approved: February 26, 2006

\begin{abstract}
The objective of this study was to verify the efficacy of cotton fabric, made of serge bonding $2 \times 1$, as microbial barrier, when new and after multiple laundering and steam sterilization procedures. The power of the microbial barrier was correlated with physical characteristics of the fabric, using standard test methods for evaluation of weight, traction, stretching tearing resistance and microbiological characteristics. The microbiological results evidenced that the microbial barrier was effective when the wrapping material was new or went through a maximum of new 65 reprocessing procedures. As for the alterations in the physical characteristics of the reprocessed material, the decrease in weight seemed to be the event responsible for microbial barrier breaking. The timing of detected alterations in bursting, traction and stretching in the wrap and the reprocessed fabrics did not coincide with the moment of bacterial barrier breaking. The present investigation corroborates that the use double cotton fabric, for wrapping medical and hospital items for steam sterilization, is safe. Re-use number must be controlled, not exceeding 65 times.
\end{abstract}

Key words: microbiological barrier, cloth packing, reprocessing, reusable medical articles

\section{INTRODUCTION}

The use of textiles to package material and linen for use in surgery started 100 years ago and up to the present date there is not a consensus on the necessary specifications of the fabric and the number of times these items can be safely reprocessed $(5-7,9,10,15,16,22)$.

Packaging should act as a protective microbial barrier throughout their useful life, and multiple reprocessing will eventually diminish the protective barrier of the material $(7,15,20)$.

The Association of Operating Room Nurses (AORN) (6) states that 280 thread count fabric should have a life time up to
75 laundering and sterilization procedures before it presents microbial barrier breaking. AORN (7) suggests that visual evaluation of the fabric may indicate the ineffectiveness of the barrier but there are no well designed studies to support this and the available ones present conflicting results. Schwartz and Saunders (21) studied 270 thread count cotton gowns and concluded that they did not loose their microbial barrier characteristics after 100 cycles of reprocessing. The main problem with this study is that the methods used were not well described.

The Association of Non-Woven Fabrics Industry (INDA) (8) suggested that the capacity of cotton surgical linen declines rapidly after 25 cycles.

*Corresponding Author. Mailing address: Comissão de Controle de Infecção Hospitalar do Instituto de Psiquiatria, Hospital das Clínicas da Faculdade de Medicina da Universidade de São Paulo, Av. Dr. Ovídio Pires de Campos, 785, $1^{\circ}$ andar, Cerqueira César. 05403-010, São Paulo, SP, Brasil. Tel.: (+5511) 3069-6520, Fax: (+5511) 3069-7800. E-mail: edna.rodrigues@ honet.usp.br 
Polyester fabrics have been studied in more depth than cotton and it has been demonstrated that there is no significant change in fabric weight before and after 25 and 50 laundering procedures $(17,18)$.

In 2004 Brazilian authors evaluated 100\% cotton single layer surgical drapes submitted to multiple reprocessing cycles and observed that the microbial barrier was broken after the $6^{\text {th }}$ cycle (11).

In Brazilian hospitals it is common practice to use double cotton packaging for material and linen used in surgery as hospital budgets are very limited.

To evaluate the safety of such practices our study aimed to evaluated the alterations of the physical characteristics, effectiveness as a microbial barrier of double cotton wraps when new and after multiple cycles of laundering and steam sterilization.

\section{MATERIALS AND METHODS}

This is an experimental laboratory study, reproducing field conditions.

New double $100 \%$ cotton fabric wrappers were used. Characteristics and technical specifications: bonding - serge 2 x 1 ; thickness- $0.40 \mathrm{~mm} \pm 0.05 \%$; weight $210 \mathrm{~g} / \mathrm{m} 2 \pm 0.05 \%$; resistance to traction $-12.5 \mathrm{daN} / \mathrm{cm}$ in warp and 5.5 in fill $(3,4)$.

Serge fabric used in this experiment was manufactured by Santista Textile ${ }^{\circledR}$ (São Paulo, Brazil). The wraps were made by Hamuche $^{\oplus}, 1.00 \mathrm{~m}$ wide and $1.00 \mathrm{~m}$ long, presenting a red square printed image of a $5 \mathrm{~cm} X 5 \mathrm{~cm}$ in the middle of the wrap, thus defining its outer side and pinpointing the exact place for the bacterial tests. The sample was constituted of 120 wraps for the wearing out, microbiological and physical tests. Each wrap received an alpha numerical sequential identification with indelible paint. After each laundering and steam sterilization cycle, the reprocessing number was registered on the fabric, correspondingly and in a sequence: R1, R2, R3, etc. Each batch contained 20 wraps. Tests were performed after R1, R25, R30, $\mathrm{R} 35, \mathrm{R} 40, \mathrm{R} 45, \mathrm{R} 50, \mathrm{R} 55 \mathrm{R} 65$ and R75. At each point 5 of the 20 wraps were randomly picked and submitted to testing.

This study was developed in three stages:

Stage 1 - Laundering, sterilization and packaging where the wearing out simulation was performed at the Heart Institute, Hospital das Clínicas, University of São Paulo. Each wrap tested was used as an external wrapper of surgical drapes in order to undergo handling tension. Next, they were submitted to steam sterilization (autoclave Baumer ${ }^{\circledR}$ High Vac $365 \mathrm{~L}$, open $134^{\circ} \mathrm{C}$ for 12 minutes) and later removed from the package and sent to the laundry to be processed as hard color cotton attire, using only stabilized hydrogen peroxide as bleacher in the washing procedure.

Stage 2-Microbiological testing for efficacy as a microbial barrier was held in the Laboratory for Medical Investigation in Bacteriology of the Hospital das Clínicas, University of São Paulo. In order to verify the efficacy of the wrap as a microbial barrier the German methodology Deutsches Institut für Normung (DIN) 58.953/87, part 6 was used - a test to detect microorganisms when specimens are subjected to humidity (13). Briefly a suspension of Staphylococcus aureus ATCC 25923 was prepared at a concentration of $10^{7}$ to $10^{8} \mathrm{CFU} / \mu \mathrm{L}$, equivalent to 0.5 on the McFarland scale. A square area measuring $5 \times 5 \mathrm{~cm}$ was marked on the center of each wrap. On 5 points of the square $100 \mu \mathrm{L}$ of the bacterial suspension were inoculated and dried a under laminar flow. After this the other side of the wraps was pressed against a Petri dish with blood agar and the dish was incubated for $72 \mathrm{~h}$ at $36^{\circ} \mathrm{C}$. The number of colony-forming (cfu) was counted when growth occurred. This procedure was repeated for 5 of the 20 wraps from each batch. Growth of less than 5 CFU was considered negative. The tests were done after R1; R25; R30; R35; R40; R45; R50; R55; R65; R70; and R75.

Stage 3 - After the microbiological test the 5 wraps of R1; $\mathrm{R} 25 ; \mathrm{R} 50 ; \mathrm{R} 65 ; \mathrm{R} 70 ; \mathrm{R} 75$; and a new wrap underwent the physical tests for the evaluation of fabric resistance at the Laboratory for Quality Control of the Technical School Francisco Matarazzo, from the National Service for Industrial Apprenticeship (SENAI). Weight determination was done according to NBR 17.006/88 (2); bursting test resistance according to DIN 53.861/78 (12) and traction and stretching resistance according to Grab's test (American Society for Testing and Materials Method - ASTM D 5.034/95) (1). Briefly weight expressed as $\mathrm{g} / \mathrm{m}^{2}$ was determined using 5 circular samples measuring $100 \mathrm{~cm}^{2}$ of each double wrap using an analytical balance (Mettler ${ }^{\oplus}$ PC 440). The mean result of the 25 samples was determined. Bursting strength was determined using Werkstoffprüffmaschinem ${ }^{\circledast}$ model BP 30 , that measured resistance of fabric to an abrupt air flow. The test was done just below the area used for weight determination. The mean pressure necessary to rupture the wraps was expressed as kgf/ $\mathrm{cm}^{2}$. Resistance to traction and stretching was determined by obtaining 10 specimens measuring $15 \times 10 \mathrm{~cm}$, diagonally across the wraps (5 in each direction). Traction was applied and the mean results for each direction (fill and wrap) were expressed as kgf. Ten specimens of each wrap were stretched using a dynamometer Instron ${ }^{\circledast}$ model 4505 the until rupture. Stretching was expressed as the proportion of increase in relation to the initial length, and five tests were done for each direction (fill and warp). Results were the expressed as the mean for 5 wraps.

\section{RESULTS}

The results of the microbiological tests evidenced that test wraps submitted to up to 65 reprocessing procedures performed effectively as a microbial barrier. At R70 and R75 6 of 10 samples were positive. 
Table 1. Evaluation of microbiological permeability of double cotton test wraps, submitted to reprocessing (laundering, sterilization and packaging).

\begin{tabular}{|c|c|c|c|c|c|c|c|c|c|c|c|c|}
\hline \multirow[t]{2}{*}{ Culture Results } & \multicolumn{12}{|c|}{ Number of Reprocessing Cycles } \\
\hline & 1 & 25 & 30 & 35 & 40 & 45 & 50 & 55 & 65 & 70 & 75 & Total $(\%)$ \\
\hline No Growth (-) & 5 & 5 & 5 & 5 & 5 & 5 & 5 & 5 & 5 & 1 & 1 & $47(85)$ \\
\hline Growth < than 5 CFU (-) & 0 & 0 & 0 & 0 & 0 & 0 & 0 & 0 & 0 & 0 & $2 * *$ & $2(4)$ \\
\hline Growth > than 5 CFU $(+)$ & 0 & 0 & 0 & 0 & 0 & 0 & 0 & 0 & 0 & $4 * * *$ & $2 * * * *$ & $6(11)$ \\
\hline & $5^{*}$ & 5 & 5 & 5 & 5 & 5 & 5 & 5 & 5 & 5 & 5 & $55(100)$ \\
\hline
\end{tabular}

* 5 wraps were tested at each stage;

** Culture with growth < 5 CFU was considered negative;

*** $22 \mathrm{CFU}$; $30 \mathrm{CFU}$; $66 \mathrm{CFU} ; 55 \mathrm{CFU}$;

$* * * * 6 \mathrm{CFU} ; 7 \mathrm{CFU}$.

Table 1 shows the results of the microbiological study.

As for the results of the physical testing (Table 2), weight increased until the $25^{\text {th }}$ reprocessing cycle and wraps started to lose mass per area in relation to the new fabric from reprocessing cycle number 65 . After repeated reprocessing cycles the weight progressively fell and when it reached levels below those of new fabric the microbial barrier was lost. There seemed to be no correlation between the efficacy of the microbial barrier and the modification of the other physical characteristics studied.

In the bursting test, there was an important decrease after the $25^{\text {th }}$ reprocessing procedure.

Traction decreased progressively over time and at R75 presented results approximately 50\% lower than new fabrics. After 75 reprocessing cycles stretching in the fill direction was similar to that of new fabric. Stretching in the warp direction however decreased progressively over time.

Table 2. Mean values for weight, tearing, traction and stretching of double cotton test wraps submitted reprocessing (laundering, sterilization and packaging).

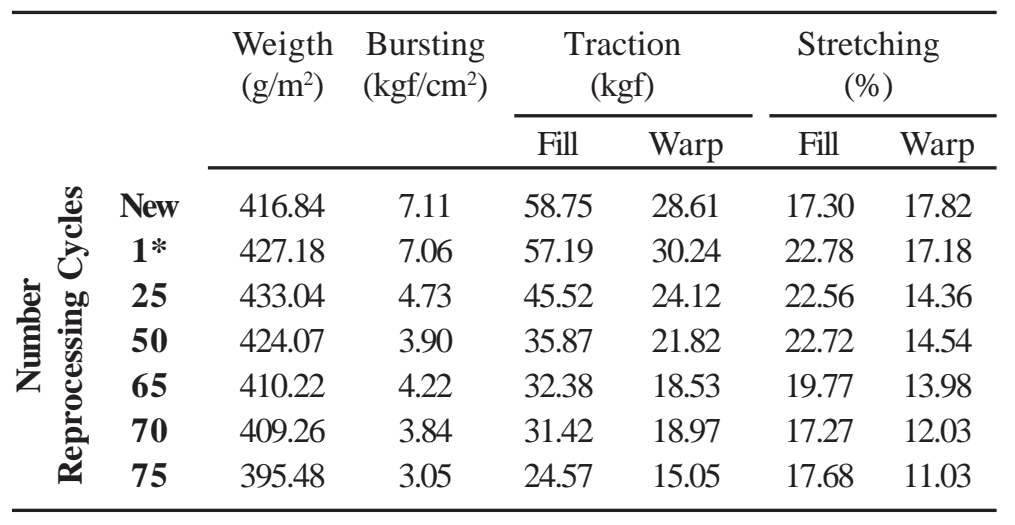

$*$ at each stage 5 wraps were studied.

\section{DISCUSSION}

In our study we demonstrated that the use of reprocessable cotton wraps to package material and linen for surgical procedures, a traditional and cheap practice, can be used safety as a microbial barrier for up to 65 reprocessing cycles.

The failure of the microbial barrier occurred simultaneously with the marked decrease in fabric weight. Initially with reprocessing weight increased and this may be explained by the fact that cotton retains water up to $25 \%$ of its original mass readjusting the threads of the fabric $(14,19)$.

When planning this study, we intended to incorporate the aggressive conditions to which wrapping fabrics are submitted on a daily basis in a real life situation, that is, during laundering, drying, transportation, handling and sterilization processes. The laboratory phase of this research, analyzing the microbiological and the physical characteristics, comprehended controlled experiments which were more aggressive than routine events that occur with woven wraps in real life situations in healthcare facilities.

Healthcare facilities, when faced with the option of buying single-use surgical attires, base their decision on information provided by manufacturers on their product, very often, with no normative references. In case the decision falls upon reusable attires, the choice will probably rely on cost or some other subjective criteria which will not qualify the material. A subjective evaluation of the reusable articles, comprising visual or functional inspection, might direct its discharging with no standard method to quantify its wearing out.

Countries which have established an institutional practice of intensive and extensive consumption of disposable items are currently being pressured to reconsider this situation. Controlling the impact of waste accumulation has become a costly problem and 
a major issue when the unbalanced environment is addressed. In the United States, the estimated annual cost for total waste disposal is about 3.6 billion dollars. From this total, $15 \%$ refers to hospital waste (16).

Schwartz and Saunders (21) believe that the cost of disposable surgical gowns is higher than the cost of reusable ones. In opposition, the World concern with the decrease of water reserves and the increased chemical water pollution caused by industries and laundries are undeniable.

In conclusion, the double cotton wraps for packing medical and hospital articles, were efficient as a microbial barrier against Staphylococcus aureus ATCC 25923 in up to 65 reprocessing procedures.

The decrease of weight seems to be the element to theoretically support microbial barrier breaking from the $65^{\text {th }}$ reprocessing cycle onwards.

\section{RESUMO}

\section{Avaliação do uso e reuso de tecido de algodão como embalagem de artigos médico-hospitalares}

O objetivo deste estudo foi verificar a efetividade do tecido de ligamento sarja 2 x 1, usado na confecção de campos duplos de algodão para a embalagem de artigos médico-hospitalares como barreira microbiana eficaz, enquanto novos e após múltiplas lavagens e autoclavações e correlacionar a quebra do poder de barreira microbiana com as alterações das características físicas do tecido. Foram utilizados métodos de testes padronizados tanto para a avaliação das características físicas para a determinação da gramatura, resistência a ruptura, resistência a tração e alongamento quanto para as microbiológicas. Os resultados microbiológicos demonstraram a efetividade da barreira microbiana da embalagem em estudo enquanto novos e, na determinação do número máximo de reprocessamentos, indicaram o número limite de 65. Quanto às alterações das características físicas do tecido reprocessado, a diminuição da gramatura foi o acontecimento que sustentou a quebra da barreira microbiana. O momento da alteração constatada nas medidas físicas de estouro, tração e alongamento no urdume e na trama dos tecidos reprocessados não coincidiu com o da quebra de barreira microbiana. A presente investigação sustenta a segurança do uso do tecido de algodão como embalagem de artigos médico hospitalares na esterilização por calor úmido. O número de reusos deverá ser controlado, não excedendo o de 65 vezes.

Palavras-chave: barreira microbiana, embalagem de tecido, reprocessamento, artigos médico-hospitalares reutilizáveis

\section{REFERENCES}

1. American Society for Testing and Materials. ASTM D 5034-75 a Standard test method for breaking strength and elongation of textile fabrics (grab test). In: 1995 Annual book of ASTM standards, ASTM, Philadelphia, 1995, p.659-666.

2. Associação Brasileira de Normas Técnicas. NBR 17006 Materiais têxteis - determinação da gramatura de tecidos. ABNT, Rio de Janeiro, 1988.

3. Associação Brasileira de Normas Técnicas. NBR 13917 - Material têxtil - tecido plano de $100 \%$ algodão para roupas profissionais e uniformes. ABNT, Rio de Janeiro, 1997a.

4. Associação Brasileira de Normas Técnicas. NBR 14028 - Roupa hospitalar - confecção de campo duplo. ABNT, Rio de Janeiro, 1997b.

5. Association for the Advancement of Medical Instrumentation. AAMI TIR $n^{\circ} 11$ - Selection of surgical gowns and drapes in health care facilities. AAMI, Arlington, 1994.

6. Association of Operating Room Nurses. Recommended practices for aseptic barrier materials for surgical gowns and drapes. AORN J. 47, 572-576, 1988.

7. Association of Operating Room Nurses, AORN. Recommended practices for selection and use of packing systems. In: Standards, recommended practices, and guidelines. AORN, Denver, 2004, p.329-334.

8. Association of the Non-Wovens Industry - INDA. Facts about singleuse and reusable drapes and gowns. Cary, INDA, 1993.

9. Beck, W.C.; Carlson, W.W. Aseptic barriers. Arch. Surg., 87, 288295, 1963.

10. Belkin, N.L. Gowns: selection on a procedure-driven basis. Infect. Control Hosp. Epidemiol., 15, 713-716, 1994.

11. Burgatti, J.C.; Possani, J.F.; Moderno, A.M.B. Avaliação da barreira microbiana do campo cirúrgico simples de algodão. Rev. SOBEC. 9, 24-32, 2004.

12. Deutsches Institut für Normung. DIN 53.861 Part 2. Testing of textiles; vaulting test and bursting test, method of test. DIN, Berlin, 1978.

13. Deutsches Institut für Normung. DIN 58.953 Part.6. Sterilization paper for bags and tube packing testing. DIN, Berlin, 1987.

14. Erhardt, T.; Blümcke, A.; Bürger W.; Märklin M.; Quinzler, E. Curso técnico têxtil. E.P.U., São Paulo, 1976, 55p.

15. International Organization for Standardization. ISO 11607 - 1997. Packaging for terminally sterilized medical devices. ISO, Genève, 1997.

16. Kennedy, P.; Reichert, M.; Thorsfeldt, H.A. Packaging in the health care facility. In: Reichert, M.; Young, J.H. Sterilization technology for the health care facility. Aspen Publishers, Maryland, 1993, p.40-57.

17. Leonas, K.K. Effect of laundering on the barrier properties of reusable surgical gowns. Am. J. Infect. Control., 26, 368-374, 1998.

18. Leonas, K.K.; Jinkins, R.S. The relationship of selected fabric characteristics and the barrier effectiveness of surgical gown fabrics. Am. J. Infect. Control., 25, 16-23, 1997.

19. Medeiros, A. Cálculo estrutural de tecidos planos. Contêxtil, São Paulo, 1995, 100p.

20. Seaman, R.E. The challenge of barrier testing. AORN J., 31, 213220, 1980.

21. Schwartz, J.T.; Saunders, D.E. Microbial penetration of surgical gown materials. Surg. Gynecol. Obstet., 150, 507-512, 1980.

22. Stanewick, B.; Taylor, J.L. Textiles. In: Reichert, M.; Young, J.H. Sterilization technology for the health care facility. Aspen Publishers, Maryland, 1993, p.71-77. 